\title{
Role of awareness on cervical cancer screening uptake among HIV positive women in Addis Ababa, Ethiopia. A cross-sectional study
}

\section{Kassahun Emru}

Institution for health care improvement

Tsega-Ab Abebaw ( $\square$ tsega.ab1@gmail.com )

Adama Hospital Medical College

Admas Abera Abaerei

Haromaya University

Research article

Keywords: Cervical cancer, HIV, Screening, Women, Awareness

Posted Date: December 19th, 2019

DOI: https://doi.org/10.21203/rs.2.19261/v1

License: (c) (i) This work is licensed under a Creative Commons Attribution 4.0 International License.

Read Full License 


\section{Abstract}

Background: Cervical cancer is the second commonest cancer among women living in less developed countries. Women infected with the Human Immunodeficiency Virus (HIV) are at increased risk. However cervical cancer screening for HIV infected women has been started in limited centers in Addis Ababa, data on the uptake of this service are lacking. Therefore, this study aimed to assess the level and predictors of cervical cancer screening uptake among HIV positive women in Addis Ababa, Ethiopia.

Methods: A cross-sectional study was conducted using a structured questionnaire on 411 HIV infected women in St. Paul's and Zewditu Hospitals, from April 20, 2015-May 10, 2015. Both bivariate and multivariable logistic regression analyses were performed to assess predictors of cervical cancer screening uptake.

Results: Only $25.5 \%$ of the respondents had undergone cervical screening. Respondents who hadn't heard about cervical cancer and the screening were $75 \%$ and $78 \%$ less likely to be screened than those who had heard about it respectively.

Conclusion: The uptake of cervical cancer screening was very low. Awareness about cervical cancer and screening were predictive factors. To increase the level of screening, specific awareness programs should be implemented by relevant authorities. Keywords: Cervical cancer, HIV, Screening, Women, Awareness

\section{Background}

Cervical cancer is primarily ascribed to persistent infection with a high risk oncogenic Human papillomavirus (1). Globally, more than 2.7 million women are at risk of cervical cancer (2). It is the fourth most common cancer globally and the second among women living in less developed countries (3) with an estimated 445, 000 new cases in 2012 (4).

Women who are infected with the Human Immunodeficiency Virus (HIV) are at increased risk of human papillomavirus infection, cervical cancer, and precancerous lesions compared with uninfected women (5, 6 6). Cervical cancer is about 8 times more prevalent in HIV infected women than uninfected ones (8) and the risk of developing invasive cervical cancer in HIV infected women is ten years earlier than uninfected women (7). In sub-Saharan Africa, women living with HIV infection comprise $60 \%$ among the 34.8 new cases of cervical cancer per 100,000 women annually (9). In this region, where cervical cancer is endemic, HIV infection has become one of the foremost causes of mortality in women and this makes the relations between the diseases a major public health problem (4).

Among Ethiopian women, cervical cancer is the second leading cause of cancer morbidity and mortality. The 2012 estimate showed that the age-standardized incidence rates of cervical cancer of Ethiopia were 26.4 cases per 100,000 women. It also noted that about 4,732 cervical cancer mortalities occurred annually and the age-standardized mortality rate was $18.4 / 100,000$ (10). Nearly a quarter $(22.1 \%)$ of Southern Ethiopia HIV infected Women were positive for precancerous cervical cancer (11). 
Cervical cancer is the only gynecologic cancer for which screening test is available that can detect its precancerous stage (12). It is also one of the most preventable cancers due to its slow progression, identifiable cytological precursors and effective treatment (13). Therefore, integrating cervical cancer prevention within HIV care services will not only decrease the morbidity and mortality linked with invasive cervical cancer but will also improve HIV treatment outcomes $(14,15)$.

Though cervical cancer screening for HIV infected women has been started in limited centers in Addis Ababa including our study areas, data on the uptake of this service and its predictors are lacking. Therefore, this study aimed to explore the rate of cervical cancer screening uptake and its predictors among HIV positive women in St. Paul's and Zewditu Hospitals, Addis Ababa, Ethiopia. The study will provide health planners and organizations working on cervical cancer and HIV/ Acquired Immunodeficiency Syndrome (AIDS) with useful information on the prevention of cervical cancer mortality and morbidity in HIV infected women through a better uptake of cervical cancer screening.

\section{Methods}

\section{Study Area and Period}

The study was conducted at Addis Ababa St. Paul's and Zewditu Hospitals, from April 20, 2015 - May 10, 2015. Addis Ababa is the capital city of Ethiopia and it has 10 sub-cities. At the time of this study, there were a total of 13 public hospitals and 80 functional public health centers. The two hospitals were among the facilities selected in Ethiopia to provide Cervical Cancer screening service for HIV positive women two years before the study period.

\section{Study design}

Healthcare institution-based cross-sectional study was conducted.

\section{Source and Study population}

Source population. All women of reproductive age group (15-49 years) visiting Zewditu and St. Paul's Hospitals for anti-retroviral therapy (ART) follow up and Pre-ART.

Study population: Those who were selected by using systematic random sampling technique.

\section{Sample size}

Sample size was determined using a single population proportion formula which is stated as, $n=Z^{2} p(1-$ $p$ ) $/ d^{2}$ (where ' $n$ ' is the desired sample size, ' $Z$ ' is the value of standard normal variable at $95 \%$ confidence interval, ' $p$ ' is the proportion of cervical cancer screening service uptake: which was assumed to be fifty 
percent and ' $d$ ' is the marginal error which was assumed to be $5 \%$ ). With adding a $10 \%$ non-response rate, the last sample size was calculated to be 424 .

\section{Sampling procedure}

The total numbers of clients who were eligible for the test were estimated using the last quarter report of the two hospitals. Afterward, the samples were allocated proportionally to the estimated size of clients for the study period of each hospital. Accordingly, 201 samples from St. Paul's and 223 from Zewditu Hospitals were taken. Finally, using a systematic random sampling technique, a sampling fraction of every $12^{\text {th }}$ eligible clients from Zewditu and $11^{\text {th }}$ from St. Paul's Hospitals were included in the study.

\section{Inclusion and Exclusion criteria}

Inclusion criteria: HIV positive women in the reproductive age group enrolled for ART/Pre-ART follow up at Zewditu and St. Paul's Hospitals during the data collection period were nominees of the study.

Exclusion criteria: Those who were newly enrolled during the data collection time were left out.

\section{Variables}

Dependent variable: Cervical cancer screening status.

Independent variables. Age, religion, marital status, occupation, income, level of education, awareness about cervical cancer, awareness about cervical cancer screening and duration of HIV infection.

\section{Data collection procedures}

Data was collected using a pretested and structured questionnaire through a face to face interview.

\section{Data quality control}

The questionnaire was first developed in English and translated to Amharic and it was again translated back to English. The review was made by different individuals to control the consistency of the translation. The tool was pre-tested on $5 \%$ of the sample size at Black Lion Hospital to see the accuracy of responses, the clarity of language and the appropriateness of the tool. Four data collectors and one supervisor were trained for a day about objectives of the study, data collection methods, and ethical considerations. Completeness and logical consistency of the collected data was checked by the investigators at the data collection site. Data coding, entry, and cleaning was performed by the investigators. 


\section{Data management and Data analysis}

The data was cleaned, coded and entered using Epi Info version 7. Then, it was exported to SPSS version 21 for analysis. Frequencies and summary statistics were used to describe the study population with relevant variables and outlines. Bivariate logistic regression model for first events was used to study the association between cervical cancer screening status and other independent variables. Then, all variables with a liberal p-value of less than 0.20 in the bivariate logistic regression analysis were taken into the multivariable logistic regression model to identify the independent effect of different factors on cervical cancer screening status. A p-value less than 0.05 and adjusted odds ratio with a $95 \%$ confidence interval were used to determine the presence and degree of association between dependent and independent variables.

\section{Results}

A total of 424 HIV positive women were included in the study. The response rate was 411 (97\%).

\section{Socio-demographic characteristics}

Majority of the respondents were in the age group of $15-34$ years. Among the respondents, $47.7 \%$ were married, $38.4 \%$ had completed secondary education, $75.7 \%$ were employed and $65.9 \%$ were Orthodox Christians. More than half (54.3\%) of the respondents had lived over 60 months after the first diagnosis of HIV infection (Table 1).

\section{Awareness about cervical cancer}

Most of the respondents (81.8\%) had heard about cervical cancer. It was believed by $90.2 \%$ and $88.1 \%$ of the respondents that, cervical cancer could be prevented and treated respectively (Table 2). 
Table 1

Socio-demographic characteristics of HIV positive women attending ART clinic in St. Paul's and Zewditu Hospitals, Addis Ababa, Ethiopia, April/May $2015(n=411)$.

\begin{tabular}{|c|c|c|c|}
\hline Variables & Category & $\begin{array}{l}\text { Number } \\
(411)\end{array}$ & $\begin{array}{l}\text { Percent } \\
(\%)\end{array}$ \\
\hline \multirow[t]{3}{*}{ Age Group (in years) } & $15-34$ & 143 & 34.8 \\
\hline & $35-39$ & 135 & 32.8 \\
\hline & $40-49$ & 133 & 32.4 \\
\hline \multirow[t]{4}{*}{ Marital status } & Single & 99 & 24.1 \\
\hline & Married & 196 & 47.7 \\
\hline & Divorced & 62 & 15.1 \\
\hline & Widowed & 54 & 13.1 \\
\hline \multirow[t]{4}{*}{ Religion } & Orthodox & 271 & 65.9 \\
\hline & Muslim & 73 & 17.8 \\
\hline & Protestant & 57 & 13.9 \\
\hline & Catholic & 10 & 2.4 \\
\hline \multirow[t]{5}{*}{ Ethnic group/ Race } & Amhara & 224 & 54.5 \\
\hline & Oromo & 114 & 27.7 \\
\hline & Tigre & 26 & 6.3 \\
\hline & SNNP & 41 & 10 \\
\hline & Others & 6 & 1.5 \\
\hline \multirow[t]{5}{*}{ Level of education } & Illiterate & 87 & 21.2 \\
\hline & Primary & 100 & 24.3 \\
\hline & Secondary & 158 & 38.4 \\
\hline & Diploma & 59 & 14.4 \\
\hline & $\begin{array}{l}\text { Degree and } \\
\text { above }\end{array}$ & 7 & 1.7 \\
\hline \multirow{4}{*}{$\begin{array}{l}\text { Duration after the first diagnosis of HIV infection (in } \\
\text { months) }\end{array}$} & $<6$ & 17 & 4.1 \\
\hline & $6-11$ & 38 & 9.2 \\
\hline & $12-23$ & 27 & 6.6 \\
\hline & $24-35$ & 37 & 9 \\
\hline
\end{tabular}




\begin{tabular}{|llll|} 
& $36-59$ & 69 & 16.8 \\
\cline { 2 - 4 } & $>60$ & 223 & 54.3 \\
\hline Employment status & Government & 127 & 30.9 \\
\cline { 2 - 4 } & Private & 184 & 44.8 \\
\hline Income (in Ethiopian birr) & Not employed & 100 & 24.3 \\
\hline
\end{tabular}


Table 2

Awareness about cervical cancer and screening among HIV positive women attending ART clinic in St.

Paul's and Zewditu Hospitals, Addis Ababa, Ethiopia, April/May $2015(\mathrm{n}=411)$.

\begin{tabular}{|c|c|c|c|}
\hline Variables & Category & $\begin{array}{l}\text { Number } \\
(411)\end{array}$ & $\begin{array}{l}\text { Percent } \\
(\%)\end{array}$ \\
\hline \multirow{2}{*}{$\begin{array}{l}\text { Ever heard about cervical } \\
\text { cancer }\end{array}$} & Yes & 336 & 81.8 \\
\hline & No & 75 & 18.2 \\
\hline \multirow{2}{*}{$\begin{array}{l}\text { Ever heard about cervical } \\
\text { cancer screening }\end{array}$} & Yes & 312 & 76.1 \\
\hline & No & 99 & 23.9 \\
\hline \multirow[t]{3}{*}{ Source of information about screening } & Electronic media & 49 & 15.7 \\
\hline & Health personnel & 258 & 82.7 \\
\hline & Other sources & 5 & 1.6 \\
\hline \multirow{4}{*}{$\begin{array}{l}\text { Sign and symptoms of } \\
\text { cervical cancer }\end{array}$} & Vaginal bleeding & 106 & 31.5 \\
\hline & $\begin{array}{l}\text { Pain during sexual } \\
\text { intercourse }\end{array}$ & 97 & 28.9 \\
\hline & Watery vaginal discharge & 28 & 8.3 \\
\hline & Don't know & 151 & 44.9 \\
\hline \multirow[t]{3}{*}{ Could cervical cancer be treated? } & Yes & 296 & 88.1 \\
\hline & No & 8 & 2.4 \\
\hline & Don't know & 32 & 9.5 \\
\hline \multirow{2}{*}{$\begin{array}{l}\text { At which stage it has the best treatment } \\
\text { outcome? }\end{array}$} & Early-stage & 275 & 92.9 \\
\hline & Don’t know & 21 & 7.1 \\
\hline \multirow{5}{*}{$\begin{array}{l}\text { What are the predisposing factors for } \\
\text { cervical cancer? }\end{array}$} & Multiple sexual partners & 305 & 90.8 \\
\hline & $\begin{array}{l}\text { Low immunity due to } \\
\text { HIV/AIDS }\end{array}$ & 286 & 85.1 \\
\hline & Smoking & 171 & 50.8 \\
\hline & Starting sex early & 216 & 64.3 \\
\hline & $\begin{array}{l}\text { Sexually transmitted } \\
\text { infections }\end{array}$ & 175 & 52.1 \\
\hline \multirow{3}{*}{$\begin{array}{l}\text { Could a healthy-looking person have cervical } \\
\text { cancer? }\end{array}$} & Yes & 324 & 96.4 \\
\hline & No & 4 & 1.2 \\
\hline & Don't know & 8 & 2.4 \\
\hline
\end{tabular}


Could cervical cancer be prevented?

Yes

303

90.2

No

4

1.2

Don't know

29

8.6

How could cervical cancer be prevented?

\begin{tabular}{lcc} 
Seeking screening service & 213 & 70.3 \\
\hline Early treatment for STIs & 150 & 49.5 \\
\hline $\begin{array}{l}\text { Sticking to one sexual } \\
\text { partner }\end{array}$ & 283 & 93.4 \\
\hline
\end{tabular}

Avoid smoking

141

46.5

\section{Awareness about cervical cancer screening}

From the total respondents, $76.1 \%$ had heard about cervical cancer screening. The source of information among those who had heard about the screening was health personnel in the majority of the cases (82.7\%). A significant number of respondents (16.5\%) didn't know where the screening is available while $83.5 \%$ responded that it is available in hospitals and clinics.

\section{Screening status}

Though the majority of the respondents had heard about the screening and know where it is available, only $105(25.5 \%)$ of the total respondents had undergone the screening.

\section{Reasons for not being screened}

From the 306 of respondents who weren't screened, the reasons mentioned for not taking the screening service were; lack of awareness about the screening (27.1\%), fear of positive result (15.7\%), fear of painful procedure $(14.1 \%)$, long waiting time to get the service $(1 \%)$, has no sign to worry $(22 \%)$, believe they don't have a disease (10.2\%), failed to get partner's approval (5.8\%) and the rest $4.1 \%$ mentioned different other reasons.

\section{Factors associated with screening status}

Association between the dependent variable and every independent variable was tested using binary logistic regression analysis. Then, multivariable binary logistic regression analysis was applied to control confounders and identify the actual factors that are significantly associated with screening status of respondents. After analysis, only two variables were found to be significantly associated with cervical cancer screening status. Awareness about cervical cancer and cervical cancer screening were the variables.

Respondents who hadn't heard about cervical cancer and the screening were 75\% (AOR $0.25[95 \% \mathrm{Cl} 0.08$, $0.81]$ ) and $78 \%$ (AOR 0.22 [95\% $\mathrm{Cl} 0.06,0.60]$ ) less likely to be screened than those who had heard about cervical cancer and the screening respectively (Table 3 ). 
Table 3

Predictors of cervical cancer screening uptake among HIV positive women attending ART clinic in St. Paul's and Zewditu Hospitals, Addis Ababa, Ethiopia, April/May $2015(\mathrm{n}=411)$.

\begin{tabular}{|c|c|c|c|c|c|}
\hline \multirow[t]{2}{*}{ Variables } & \multirow[t]{2}{*}{ Category } & \multicolumn{2}{|c|}{$\begin{array}{l}\text { Screening } \\
\text { status }\end{array}$} & \multirow[t]{2}{*}{ COR $95 \% \mathrm{Cl}$} & \multirow[t]{2}{*}{ AOR $95 \% \mathrm{Cl}$} \\
\hline & & Yes & No & & \\
\hline \multirow[t]{3}{*}{ Age } & $<35$ & 38 & 105 & 1.00 & 1.00 \\
\hline & $35-39$ & 33 & 102 & $\begin{array}{l}1.11(0.65, \\
1.92)\end{array}$ & $\begin{array}{l}1.69(0.90 \\
3.17)\end{array}$ \\
\hline & $>39$ & 34 & 99 & $\begin{array}{l}1.01(0.62 \\
1.81)\end{array}$ & $\begin{array}{l}1.15(0.59 \\
2.25)\end{array}$ \\
\hline \multirow[t]{4}{*}{ Marital status } & Single & 19 & 80 & 1.00 & 1.00 \\
\hline & Married & 63 & 133 & $\begin{array}{l}0.50 \\
(0.28,0.89)\end{array}$ & $\begin{array}{l}0.57(0.28 \\
1.15)\end{array}$ \\
\hline & Divorced & 12 & 50 & $\begin{array}{l}0.99(0.44 \\
2.21)\end{array}$ & $\begin{array}{l}1.09(0.47 \\
2.95)\end{array}$ \\
\hline & Widowed & 11 & 43 & $\begin{array}{l}0.93(0.40 \\
2.13)\end{array}$ & $\begin{array}{l}0.80(0.29 \\
2.18)\end{array}$ \\
\hline \multirow[t]{5}{*}{ Level of education } & Illiterate & 18 & 69 & 1.00 & 1.00 \\
\hline & Primary & 23 & 77 & $\begin{array}{l}0.87(0.43 \\
1.75)\end{array}$ & $\begin{array}{l}1.18(0.53 \\
2.65)\end{array}$ \\
\hline & Secondary & 41 & 117 & $\begin{array}{l}0.74(0.40 \\
1.40)\end{array}$ & $\begin{array}{l}1.07(0.50 \\
2.23)\end{array}$ \\
\hline & Diploma & 19 & 40 & $\begin{array}{l}0.55(0.26 \\
1.17)\end{array}$ & $\begin{array}{l}0.90(0.34 \\
2.38)\end{array}$ \\
\hline & $\begin{array}{l}\text { Degree and } \\
\text { above }\end{array}$ & 4 & 3 & $\begin{array}{l}0.20(0.04 \\
0.95)\end{array}$ & $\begin{array}{l}0.33(0.05 \\
1.96)\end{array}$ \\
\hline \multirow[t]{3}{*}{ Employment status } & Government & 40 & 87 & 1.00 & 1.00 \\
\hline & Private & 47 & 137 & $\begin{array}{l}1.34(0.81 \\
2.21)\end{array}$ & $\begin{array}{l}0.99 \\
1.95)\end{array}$ \\
\hline & $\begin{array}{l}\text { Not } \\
\text { employed }\end{array}$ & 18 & 82 & $\begin{array}{l}2.09 \\
3.94)\end{array}$ & $\begin{array}{l}1.17(0.47 \\
2.93)\end{array}$ \\
\hline \multirow[t]{2}{*}{ Income (in Ethiopian birr) } & $\geq 600$ & 59 & 139 & 1.00 & 1.00 \\
\hline & $<600$ & 46 & 167 & $\begin{array}{l}1.54(0.92, \\
2.22)\end{array}$ & $\begin{array}{l}1.18(0.64 \\
2.18)\end{array}$ \\
\hline
\end{tabular}




\begin{tabular}{|c|c|c|c|c|c|}
\hline \multirow[t]{4}{*}{ Religion } & Orthodox & 77 & 194 & 1.00 & 1.00 \\
\hline & Muslim & 16 & 57 & $\begin{array}{l}1.41(0.77 \\
2.61)\end{array}$ & $\begin{array}{l}1.93(0.90, \\
4.12)\end{array}$ \\
\hline & Protestant & 12 & 45 & $\begin{array}{l}1.49(0.75 \\
2.97)\end{array}$ & $\begin{array}{l}2.35(0.99, \\
5.56)\end{array}$ \\
\hline & Catholic & 0 & 10 & - & - \\
\hline \multirow[t]{5}{*}{ Ethnic group } & Amhara & 59 & 165 & 1.00 & 1.00 \\
\hline & Oromo & 28 & 86 & $\begin{array}{l}1.09(0.65, \\
1.85)\end{array}$ & $\begin{array}{l}0.75(0.39, \\
1.44)\end{array}$ \\
\hline & Tigre & 5 & 21 & $\begin{array}{l}1.50(0.54 \\
4.16)\end{array}$ & $\begin{array}{l}1.50(0.45, \\
4.96)\end{array}$ \\
\hline & SNNP & 10 & 31 & $\begin{array}{l}1.10(0.51 \\
2.40)\end{array}$ & $\begin{array}{l}0.63(0.24 \\
1.67)\end{array}$ \\
\hline & Others & 3 & 3 & $\begin{array}{l}0.36(0.07 \\
1.82)\end{array}$ & $\begin{array}{l}0.34(0.06 \\
1.95)\end{array}$ \\
\hline \multirow[t]{6}{*}{$\begin{array}{l}\text { Duration after first diagnosis of HIV } \\
\text { infection (in months) }\end{array}$} & $<6$ & 1 & 16 & $\begin{array}{l}6.16(0.80 \\
47.45)\end{array}$ & $\begin{array}{l}2.25(0.24, \\
21.44)\end{array}$ \\
\hline & $6-11$ & 3 & 35 & $\begin{array}{l}4.49(1.33 \\
15.14)\end{array}$ & $\begin{array}{l}0.79(0.17 \\
3.58)\end{array}$ \\
\hline & $12-23$ & 7 & 20 & $\begin{array}{l}1.10(0.44 \\
2.73)\end{array}$ & $\begin{array}{l}0.54(0.17, \\
1.69)\end{array}$ \\
\hline & $24-35$ & 9 & 28 & $\begin{array}{l}1.19(0.54 \\
2.68)\end{array}$ & $\begin{array}{l}1.23(0.50 \\
3.00)\end{array}$ \\
\hline & $36-59$ & 23 & 46 & $\begin{array}{l}0.77(0.43 \\
1.38)\end{array}$ & $\begin{array}{l}0.95(0.50, \\
1.80)\end{array}$ \\
\hline & $>60$ & 62 & 161 & 1.00 & 1.00 \\
\hline \multirow[t]{2}{*}{ Ever heard about cervical cancer } & Yes & 101 & 235 & 1.00 & 1.00 \\
\hline & No & 4 & 71 & $\begin{array}{l}0.13(0.05 \\
0.36)\end{array}$ & $\begin{array}{l}0.25 \\
(0.08,0.81)\end{array}$ \\
\hline \multirow{2}{*}{$\begin{array}{l}\text { Ever heard about cervical cancer } \\
\text { screening }\end{array}$} & Yes & 99 & 213 & 1.00 & 1.00 \\
\hline & No & 6 & 93 & $\begin{array}{l}0.14(0.06 \\
0.33)\end{array}$ & $\begin{array}{l}0.22(0.06, \\
0.60)\end{array}$ \\
\hline
\end{tabular}

\section{Discussion}


Cervical cancer is one of the preventable diseases. Main aspects of its prevention include early detection of the premalignant lesion through the cervical screening. This study assessed the level and predictors of cervical cancer screening uptake among HIV positive women in St. Paul's and Zewditu Hospitals, Addis Ababa, Ethiopia. Despite the recent efforts to screen at least $80 \%$ of all HIV positive women in Ethiopia, this study has found that only $25.5 \%$ of the respondents had undergone screening for cervical cancer. When compared to other similar studies, the result is comparable to $23.5 \%$ in Gondar (16) while higher than $10 \%$ in another study conducted in Gondar (17), 11.5\% in Addis Ababa (18), 19\% in Kenya (19) and $9.4 \%$ in Nigeria (20) and lower than $58 \%$ in Ottawa (21). According to the Ethiopian guideline for cervical cancer prevention and control's recommendation, the level of cervical cancer screening uptake in this study was very low.

The major reasons mentioned for not being screened in this study were lack of awareness about the screening $(27.1 \%)$, has no sign to worry $(22 \%)$, fear of positive result $(15.7 \%)$, fear of painful procedure (14.1\%), believe they don't have a disease (10.2\%). Similarly, a study conducted in Cameron revealed, majority of the respondents (25.3\%) mentioned lack of awareness as a reason for not being screened while, $5.53 \%$ believed that they were healthy and saw no need for screening and $4.35 \%$ thought it could be painful (22). A study conducted in Nigeria also mentioned lack of awareness as the major reason (23). A systematic review in Uganda also stated fear of the screening procedure or outcome was among the most frequently reported barriers (24). Lack of awareness can halt people from taking preventative action. Therefore, raising awareness about cervical cancer and screening could have an important role to avert most of the reasons mentioned by respondents and the low uptake of the screening.

According to this study, majority of the respondents (81.8\%) had heard about cervical cancer which is comparable with a similar study conducted in Gondar $87.7 \%(16)$ and significantly higher than another study conducted in Gondar (49.6\%) (17) and 56.2\% in Nigeria (20). Those who had heard about cervical cancer screening in this study were $76.1 \%$, which is higher than $37.8 \%$ from a study in Gondar (17), $42.7 \%$ in Addis Ababa (25) and 34.5\% in Nigeria (20). The source of information in the majority of the cases was health personnel which was similar to other study conducted in Addis Ababa (18). This could be explained by the fact that the study population has a higher rate of health care facility visit for regular follow up and filling of medication.

Respondents who hadn't heard about cervical cancer were 75\% (AOR $0.25[95 \% \mathrm{Cl} 0.08,0.81]$ ) less likely to be screened than those who had heard about cervical cancer and who hadn't heard about cervical cancer screening were 78\% (AOR 0.22 [95\% $\mathrm{Cl} 0.06,0.60]$ ) less likely to be screened than those who had heard about cervical cancer screening. Similarly, studies conducted in Kenya and Nigeria showed that good level of awareness about cervical cancer and screening were significantly associated with uptake of screening with (OR $2.30,95 \% \mathrm{Cl}, 1.06-4.97, \mathrm{P}=0.03)$ and (OR:1.5; $95 \% \mathrm{Cl}: 1.2-2.0)$ respectively $(19,20)$. Therefore, the finding of this study implied that lack of awareness about cervical cancer and screening are significant factors for the very low level of the screening uptake.

\section{Conclusions}


The uptake of cervical cancer screening among HIV positive women in St. Paul's and Zewditu Hospitals, Addis Ababa, Ethiopia was very low. Awareness about cervical cancer and screening were predictive factors. To increase the level of screening, intervention studies and specific awareness programs about cervical cancer and screening should be designed and implemented by relevant authorities.

\section{Abbreviations}

AIDS: Acquired Immunodeficiency Syndrome

ART: Antiretroviral Therapy

HIV: Human Immunodeficiency Virus

\section{Declarations}

\section{Acknowledgements}

We would like to thank the data collectors who participated in the study. We are also grateful to both hospital's administration stuff and study subjects.

Funding: No funding was received.

Availability of data and materials: Data is available and it can be accessed when asked with reasonable inquiry.

\section{Authors' contributions}

KE conceived the study. TA and KE designed the study and performed data analysis. TA compiled the whole work and prepared the manuscript. AA participated in design, analysis, reviewing the main document and took part in the critical revision of the manuscript. All authors read and approved the final manuscript.

\section{Ethics approval and consent to participate}

Ethical clearance was obtained from the Ethical review committee of Debre Markos University, College of Medicine and Health Sciences, Department of Public Health. Hospitals were communicated through a formal letter from Addis Ababa Health Bureau and detailed explanation of the purpose and the nature of the study was given for the responsible officials and ART department assigned health care workers. A letter with the introduction of the study, method of data collection and confidentiality were attached to the cover pages of every questionnaire. Adequate information about the purpose and importance of the study, the risk and benefit of the study, and their right not to participate or withdraw at any time from the study was given to the study participants first by the data collectors. Response to the study was anonymous. Hence, the review board accepted and approved to use verbal consent, verbal consents were 
taken from all participants before starting the interview and the interviews were made in private. Even though the source population included those women aged 15-49 years, none were selected from the age group of under 16 years by the random selection of participants. Therefore, no consent was taken from parents.

Consent to publish: Not applicable

Competing interests: The authors declare no competing interests.

\section{References}

1. Zur Hausen, H. Papillomaviruses in the causation of human cancers - a brief historical account. Virology. 2009; https://doi.org/10.1016/j.virol.2008.11.046.

2. Bruni L, Barrionuevo-Rosas L, Albero G, et al. ICO Information Centre on HPV and Cancer (HPV Information Centre). Human Papillomavirus and Related Diseases in theWorld. Summary Report 2015. In HPV Centre. 2015.

3. Ferlay, J., Soerjomataram, I., Ervik, M., et al. Cancer Incidence and Mortality Worldwide. International Agency for Research on Cancer, World Health Organization. 2013; https://doi.org/223.

4. Centers For Disease Control And Prevention. HPV Fact Sheet. World Health Organization. 2011.

5. Six, C., Heard, I., Bergeron, C., et al. Comparative prevalence, incidence and short-term prognosis of cervical squamous intraepithelial lesions amongst HIV-positive and HIV-negative women. AIDS. 1998; https://doi.org/10.1097/00002030-199809000-00013.

6. Maiman, M. Management of cervical neoplasia in human immunodeficiency virus-infected women. Journal of the National Cancer Institute. Monographs. 1998;

https://doi.org/10.1093/oxfordjournals.jncimonographs.a024172.

7. Stewart, B. W., \& Wild, C. P. World cancer report 2014. World Health Organization. 2014; https://doi.org/.

8. Tanon, A., Jaquet, A., Ekouevi, D. K., et al. The Spectrum of Cancers in West Africa: Associations with Human Immunodeficiency Virus. PLoS ONE. 2012; https://doi.org/10.1371/journal.pone.0048108.

9. Bezerra, L. M. D. Global report: UNAIDS report on the global AIDS epidemic 2010. Urban Research. 2010; https://doi.org/10.1080/17535069.2010.481379.

10. Bruni, L., Barrionuevo-Rosas, L., Albero, G., et al. Human Papillomavirus and Related Diseases in the World. Summary Report 2014. ICO Information Centre on HPV and Cancer (HPV Information Centre). 2014.

11. Gedefaw, A., Astatkie, A., \& Tessema, G. A. The prevalence of precancerous cervical cancer lesion among HIV-infected women in Southern Ethiopia: A cross-sectional study. PLOS ONE. 2013; https://doi.org/10.1371/journal.pone.0084519.

12. WHO. Guidelines for screening and treatment of precancerous lesions for cervical cancer prevention. WHO Guidelines. 2013. 
13. Kawonga, M., \& Fonn, S. Achieving effective cervical screening coverage in South Africa through human resources and health systems development. Reproductive Health Matters. 2008; https://doi.org/10.1016/S0968-8080(요) 32403-3.

14. Parham, G. P., Sahasrabuddhe, V. V., Mwanahamuntu, et al. Prevalence and predictors of squamous intraepithelial lesions of the cervix in HIV-infected women in Lusaka, Zambia. Gynecologic Oncology. 2006; https://doi.org/10.1016/j.ygyno.2006.06.015.

15. Agaba, P. A., Thacher, T. D., Ekwempu, C. C., \& Idoko, J. A. Cervical dysplasia in Nigerian women infected with HIV. International Journal of Gynecology and Obstetrics. 2009; https://doi.org/10.1016/j.jijgo.2009.06.006.

16. Erku, D. A., Netere, A. K., Mersha, A. G., et al. Comprehensive knowledge and uptake of cervical cancer screening is low among women living with HIV/AIDS in Northwest Ethiopia. Gynecologic Oncology Research and Practice. 2017; 4(1), 1-7. https://doi.org/10.1186/s40661-017-0057-6.

17. Nega, A. D., Woldetsadik, M. A., \& Gelagay, A. A. Low uptake of cervical cancer screening among HIV positive women in Gondar University referral hospital, Northwest Ethiopia: Cross-sectional study design. BMC Women's Health. 2018; 18(1), 1-7. https://doi.org/10.1186/s12905-018-0579-z.

18. Belete, N., Tsige, Y., \& Mellie, H. Willingness and acceptability of cervical cancer screening among women living with HIV/AIDS in Addis Ababa, Ethiopia: a cross sectional study. Gynecologic Oncology Research and Practice. 2015; 2(1), 4-9. https://doi.org/10.1186/s40661-015-0012-3.

19. Lukorito, J., Wanyoro, A., \& Kimani, H. Uptake of Cervical Cancer Screening among HIV Positive Women in Comrehensive Care Centres in Nairobi, Kenya. Research in Obstetrics and Gynecology.2017; 5(1), 1-6. https://doi.org/10.5923/j.rog.20170501.01.

20. Ezechi, O. C., Gab-Okafor, C. V., Ostergren, P. O., \& Odberg Pettersson, K. Willingness and acceptability of cervical cancer screening among HIV positive Nigerian women. BMC Public Health. 2013; https://doi.org/10.1186/1471-2458-13-46.

21. Leece, P., Kendall, C., Touchie, C., Angel, J. B., Jaffey, J., \& Pottie, K. Cervical cancer screening among HIV-positive women Recherche les femmes VIH positives. Canadian Family Physician. 2010; 56:425-431.

22. Donatus, L., Nina, F. K., Sama, D. J., et al. Assessing the uptake of cervical cancer screening among women aged 25-65 years in Kumbo West Health District, Cameroon. Pan African Medical Journal. 2019; 33, 1-11. https://doi.org/10.11604/pamj.2019.33.106.16975.

23. O.A, A. An assessment of women's awareness and knowledge about cervical cancer and screening and the barriers to cervical screening in Ogun State, Nigeria. IOSR Journal of Dental and Medical Sciences. 2013; 10(3), 52-58. https://doi.org/10.9790/0853-1035258.

24. Black, E., Hyslop, F., \& Richmond, R. Barriers and facilitators to uptake of cervical cancer screening among women in Uganda: a systematic review. BMC Women's Health. 2019; 19(1), 1-12. https://doi.org/10.1186/s12905-019-0809-z.

25. Getachew, S., Getachew, E., Gizaw, M., et al. Cervical cancer screening knowledge and barriers among women in Addis Ababa, Ethiopia. PLoS ONE. 2019; 14(5), 1-13. 
https://doi.org/10.1371/journal.pone.0216522.

Page 16/16 